\title{
Heavy Metal and Water Turbidity Impact on Corroded Patin Fish Cages in temerloh River, Pahang, Malaysia
}

\author{
Muhamad Hellmy Hussin, NurAzida CheLah
}

\begin{abstract}
In December 2015 and usually once in a year, the population of Temerloh'spatin fish was the environmental issue gripping Pahang. The fishes, bred in special breeding cages made of y-bar steel along the riverbanks of Sungai Pahang are threatened with a massive die-off. This low water level problems becomes worsen as more forests in the upper reaches of the Ulu Jelai and Ulu Tembeling areas are cleared for timber. Instead of that, due to the low water level and high water turbidity, y-bar steel Patin fish cages facing corrosion problem in unpredicted time. Though, this paper is to investigate the impact of heavy metal and water turbidity level on corroded y-bar steel at specified location adjacent to the fish cages. In this work, samples were submerged into the Pahang river for 56 days in February 2016. The sample then must be weighing before and after being submerged. The river water samples were took out at specific time and subjected to heavy metal and water turbidity test. It was found that, the concentration of $\mathrm{Cu}$ and $\mathrm{Fe}$ and also water turbidity level that occur in water caused by fish pallet or fish food also contribute and increase the weight loss of the Y-bar.
\end{abstract}

Index Terms: Corroded Y-bar, Water turbidity, Heavy metal, Weight loss, Fish Cage

\section{INTRODUCTION}

Temerloh is the second largest town in Pahang and it is situated at the junction of the Pahang River and the Semantan River. This town has been rebranded as "Patin Fish Town". Patin fish or as known as Silver Catfish, one of the most prized freshwater fishes in Malaysia because of its juicy taste. In December 2015 and usually once in a year, the population of Temerloh'spatin fish was the environmental issue gripping Pahang [1-4]. The fishes, bred in special breeding cages made of Y-bar steel along the riverbanks of Sungai Pahang are threatened with a massive die-off. This low water level problems becomes worsen as more forests in the upper reaches of the Ulu Jelai and Ulu Tembeling areas are cleared for timber [5,6]. Fish breeders claimed that the water level in Pahang River had been gradually dropped for years due to extensive logging upstream. Thus, this issue disrupted the local water cycle. Instead of that, due to the low water level and high water turbidity, Y-bar steel Patin fish cages facing corrosion problem in unpredicted time. This issue had been affected fish breeders in Temerloh and suffering losses due to this problem.

Revised Manuscript Received on February 05, 2020.

* Correspondence Author

Muhamad Hellmy Hussin*, Fabrication \& Joining, University of Kuala Lumpur Malaysia France Institute (UNIKL MFI), Selangor, Malaysia.

NurAzida CheLah, Fabrication \& Joining, University of Kuala Lumpur Malaysia France Institute (UNIKL MFI), Selangor, Malaysia.

(c) The Authors. Published by Blue Eyes Intelligence Engineering and Sciences Publication (BEIESP). This is an open access article under the CC BY-NC-ND license (http://creativecommons.org/licenses/by-nc-nd/4.0/)
In small scale entrepreneurial business, to breed Patin fish, the fish cages are needed [7-11]. These cages are made off from Y-bar as a cages frame and weld using SMAW process. Y-bar is well known among welders. Y-bar is one type of deformed bars which is differing from the other bars and they have either indentation in them or ridges on them or both, in a regular pattern. The spiral ridges, along the surface of the Y-bar, increase its bond strength with concrete in construction industry. This type of material have a high carbon contents, low price and easy to use. In this case, instead of using other type of steel, for small scale industry, Y-bar is also used to build fish cages. By using rutile electrode type which is E6013 (rutile potassium) the Patin fish cages are build. Life stand for this cages are depend to the cages maintenance $[12,13]$. Usually the live stand for this cage is around 1- 2 years before corrosion process take place.

Practically, many structural alloys usually experienced corrosion merely from exposure to moisture especially in air. Moreover, the process can be strongly affected by exposure to certain substances [14-16]. In general, because corrosion is a diffusion-controlled process, it prominently occurs on exposed metal surfaces. As a consequence, it will deteriorate the important properties of materials and structures. This would include important factor such as strength, appearance and permeability to liquids and gases. Moreover, corrosion is the main factor that causes the life duration for fish cages to be shorted. Additionally, corrosion can be exist because of few factors such as heavy metal and water turbidity level $[17,18]$. The more acidity the water, the more easily the corrosion process will take place. Additionally, water polluted by nutrients or organic compound and the heavy metal content in flowing waters became one of the most important problems because of its toxic effect even in minor concentrations. Moreover, suspended matter such as trapped rubbish and decayed steel structure and also sedimentation caused by fish pallet or fish food work as a trap medium for dissolved heavy metals [19]. Importantly, the release from sediments may not only results from re-suspension of particulates, but also trough the activities of microorganisms within the sediments.

This work presents the study of corroded Y-bar steel sample at different depth of river water. The aims are to determine the toxicity levels of heavy metal such as copper $(\mathrm{Cu})$ and ferum $(\mathrm{Fe})$ in river water and also water turbidity level adjacent to the location of fish cages at specific location of Pahang river in Temerloh, Pahang, Malaysia. 


\section{MATERIALS AND METHODS}

\section{A. Material Preparation}

Y-bar steel was used for all the tests in this work which is the same material used to build the Patin cages at Temerloh, Pahang. The chemical composition was (wt\%): C 1.80, Cu 0.035, Mn 0.376, P 0.207, Si 1.66, S 0.179 and Fe balance and was carried out using Spectrometer Arc SpectroMax testing machine. Table 1 shows the standard mechanical properties of the specified Y-bar steel.

Table 1 Element compositions in wt \% of Y-bar steel

\begin{tabular}{|c|c|c|}
\hline $\begin{array}{c}\text { Yield Stress } \\
\left(\mathrm{N} / \mathrm{mm}^{2}\right)\end{array}$ & $\begin{array}{c}\text { Tensile Strength } \\
\left(\mathrm{N} / \mathrm{mm}^{2}\right)\end{array}$ & $\begin{array}{c}\text { Elongation } \\
(\%)\end{array}$ \\
\hline $\mathbf{4 6 0}$ & $\mathbf{1 . 0 8}$ & $\mathbf{1 4}$ \\
\hline
\end{tabular}

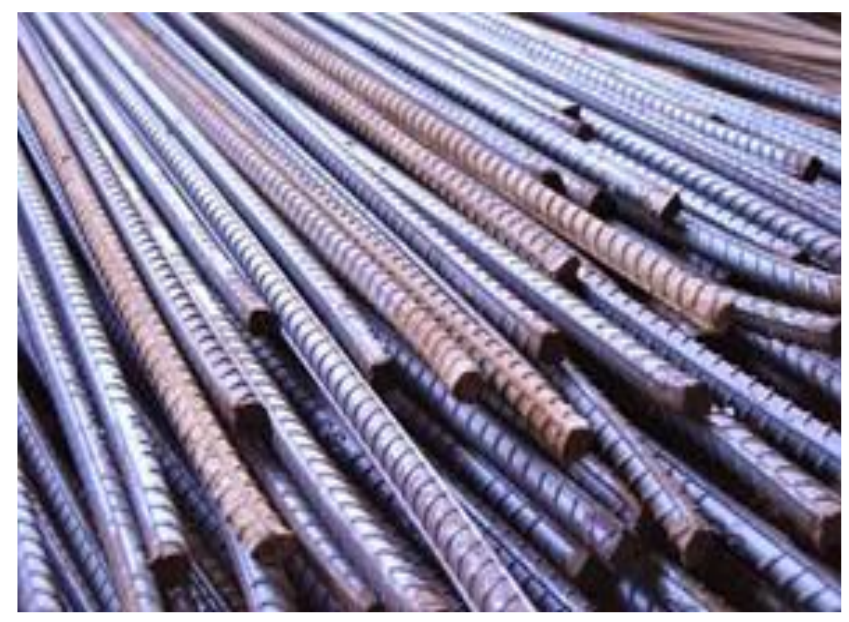

Fig. 1 Y-bar reinforced steel
Fig.1 shows the Y-bar reinforced steel used in this study. The $6 \mathrm{ft}$ Y-bar samples were cut according to the size of 30 $\mathrm{mm}$ in length and with diameter of $10 \mathrm{~mm}$. The samples surface were grounded using grinding machine to remove the unnecessary part until the ridges surface became smooth and it was done at the early stage before test measurement.

The samples were then mechanically grounded up to 1200 mesh using silicon carbide paper and followed by polishing using diamond paste ( 3 and $1 \mu \mathrm{m}$ ). After this process, the samples were rinsed with double-distilled water, then degreased in ethanol, and finally dried with air. Samples were divided into two categories which are uncoated and coated with black paint. All the coated and uncoated samples were then weighed before submerging in the river water.

\section{B. Submerge Test}

Laboratory tests are usually carried out for rapid screening, but in this work, long-term tests in real environments are useful to monitor changes in weight loss analysis with respect to time. In this case, testing of Y-bar steel in river water atmospheric and immersion conditions is done along specific Pahang riverbank in Temerloh, Pahang, Malaysia for 56 days.

Temerloh is a district in central Pahang, Malaysia with Temerloh town as the district capital as shown in Fig. 2. Temerloh is the second largest town in Pahang after Kuantan and it is situated at the junction of the Pahang River and the Semantan River. As well known, Temerloh has been rebranded as Patin Fish Town and because of its juicy taste of Patin fish, it can be considered as one of the freshwater fish in Malaysia
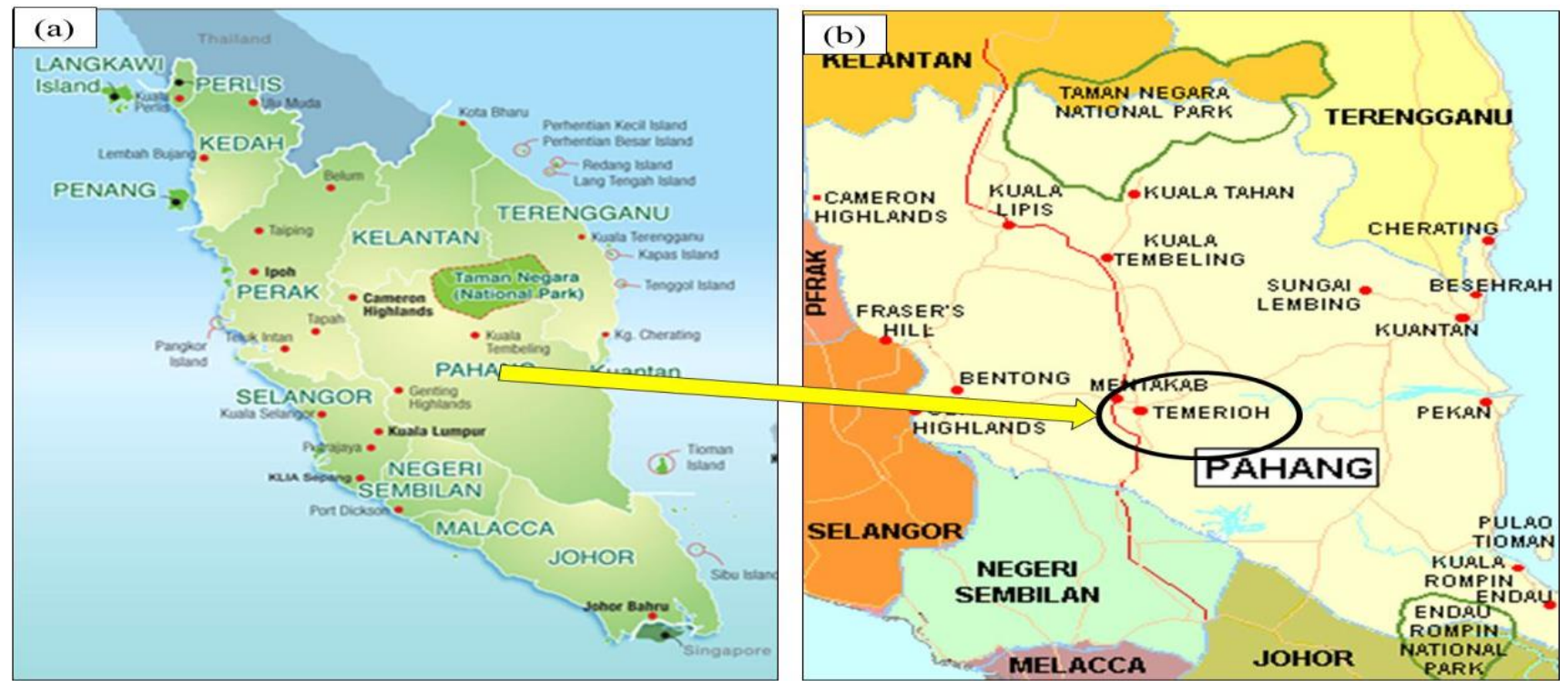

Fig. 2 Location of submerging test, (a) Map of Pahang, Malaysia, and (b) Temerloh district, Pahang, Malaysia.

Figs. 3and 4show the location of submerge test and the Patin fish cages at Temerloh, Pahang, Malaysia. The polished and pre-weighed coated and uncoated Y-bar steel samples were tighten and placed adjacent to the real Patin fish cages. All the coated and uncoated samples were submerged at 1, 2, 3 and $4 \mathrm{ft}$. depth. At the end of submerging test, the samples assessed by weight-loss measurement. The coated and uncoated samples after submerged in river water for 3 months were rinsed with double distilled water, and ethanol, dried in air, and reweighed to determine the weight loss.

Published By:

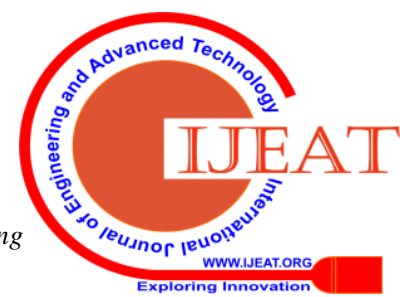




\section{Turbidity and Heavy Metal Test}

The river water samples were taken at 1, 2, 3 and $4 \mathrm{ft}$. depth adjacent to the location where the samples were submerged. In this case, the river water samples were subjected to turbidity test according to ASTM 2130. Turbidity is a measure of the extent to which light is either absorbed or scattered by suspended material in water. In this test, the turbidity is measured using turbidity meter or also known as laboratory Nephelometer. The specific reagents used in this test is diluted or filtered distilled water with filter pore size of $0.1 \mu \mathrm{m}$, stock of primary standard formazin suspension, secondary standards of commercial stock suspensions of 4000 NTU certified formazin. The turbidity measurement is reported as nephelometric turbidity units (NTU).

Meanwhile, the heavy metal test was carried out according to ASTM 3111 B to determine the concentration of metals that are toxic, for examples are nickel (Ni), cadmium (Cd), copper $(\mathrm{Cu})$, zinc $(\mathrm{Zn})$, lead $(\mathrm{Pb})$ etc.
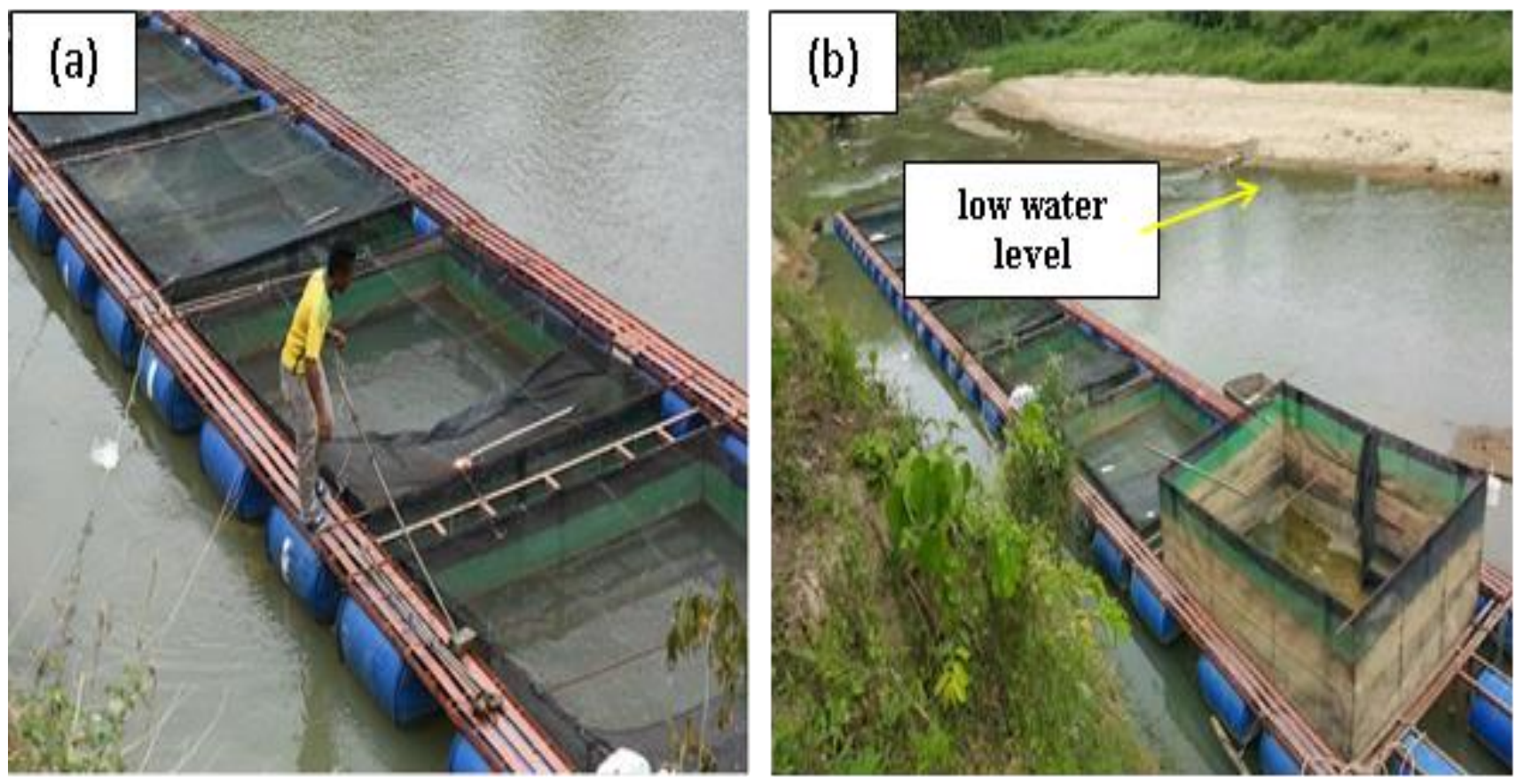

Fig. 3 (a) Patin fish cages in Temerloh, Pahang River, and (b) low water level at Pahang River specific location where the test location took place.
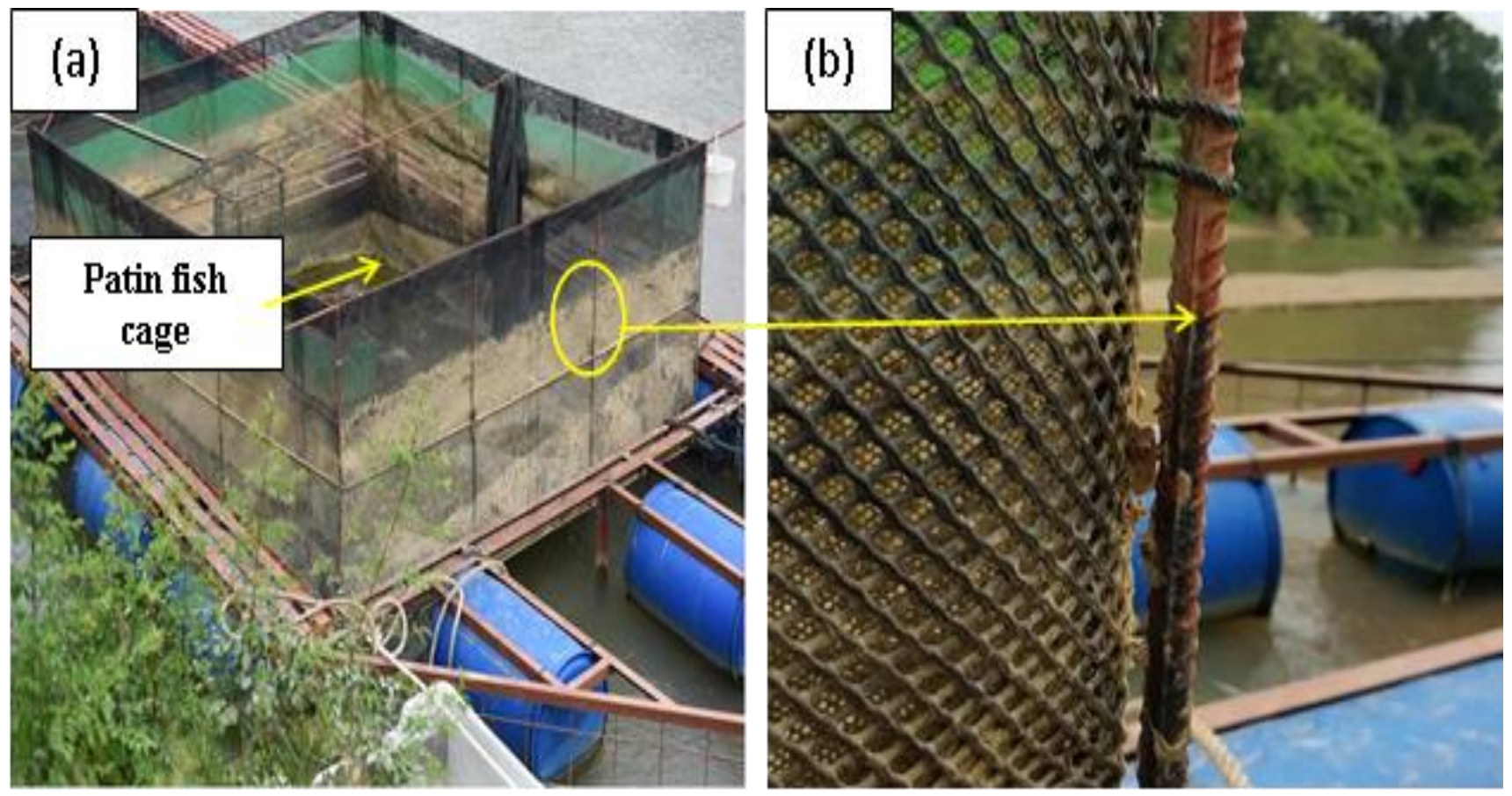

Fig. 4 (a) Patin fish cage made of y-bar steel in Temerloh, Pahang River, and (b) enlargement of y-bar steel structure of Patin fish cage.

Retrieval Number: B2862129219/2020@BEIESP

DOI: 10.35940/ijeat.B2862.029320

Journal Website: www.ijeat.org
Published By:

676 Blue Eyes Intelligence Engineering \& Sciences Publication

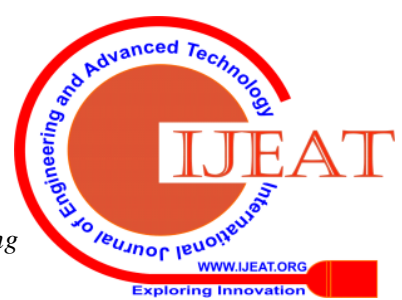




\section{RESULTS AND DISCUSSION}

Weight loss measurement is the accurate method of determining the changes of corrosion behaviour. Although in this work, real time experiment is required and long exposure times may be involved, this simple procedure may reduce the errors. In this case, the overall weight loss per unit area of Y-bar steel sample, $\mathrm{W}$, was calculated using the following:

$$
\left(\frac{\Delta W}{A}\right)=\frac{W_{f}-W_{i}}{A}
$$

where $\Delta \mathrm{W}$ is the overall weight loss of the Y-bar steel (mg), $\mathrm{W}_{\mathrm{i}}$ and $\mathrm{W}_{\mathrm{f}}$ represent the sample' $\mathrm{s}$ weight before and after submerging, and A is surface area of the sample $\left(\mathrm{cm}_{2}\right)$.

In this work, the analyses were focused on uncoated Y-bar steel samples that were submerged in river water adjacent to the location where the fish cages were located for 14, 28, 42 and 56 days. These uncoated samples show an increment of weight loss as shown in Fig. 5. It shows that, the weight loss was drastically increased after 42 and 56 days of submerging samples in river water. It also shows that after 56 days of the test, uncoated samples show higher weight loss recorded which the difference is about $80 \%$. This statement is in agreement with all the factors influenced such as heavy metal content, and water turbidity as indicated in Figs. 6 until 7.

The result of the weight loss analyses in Fig. 5 shows the effect of submerging samples of Y-bar steel in the river water. In this case, the effect of heavy metal and water turbidity of the river water itself were extensively studied to determine the factors involved in accelerating the corrosion process of Y-bar steel cage structures. The result of heavy metals in river water adjacent to the place where the sample was located is presented in Fig. 6. As well known, heavy metals are also called "trace elements" and they are basically metallic elements which can be found in the periodic table. It becomes an important interest in recent decades when it deals with the specific surrounding environmental investigation. In Fig. 6, it shows that the concentration of $\mathrm{Cu}$ ranged from 0.02 to $0.26 \mathrm{mg} / \mathrm{l}$ in the river water sample. The lower limit of $\mathrm{Cu}$ in the river water sample was determined at $1 \mathrm{ft}$. depth location and the upper limit at $4 \mathrm{ft}$. depth. Meanwhile, the concentrations of $\mathrm{Fe}$ in river water sample was higher compared to the concentration of $\mathrm{Cu}$. Similar pattern was found for Fe concentration and it shows that the lower limit of Fe was determined at $1 \mathrm{ft}$. depth and the upper limit was recorded at $4 \mathrm{ft}$. depth.

According to the Fig. 6, there were variations in the concentrations of heavy metal depends on the depth of river water where the samples were submerged. This could be attributed to the lower volume of water due to the lack of water flow from the Tembeling and Jelai rivers upstream that flow into Sungai Pahang in July till December 2015. Thus, this will influenced the high concentrations of some metals measured at the low water level area adjacent to the place where the samples were submerged.

As well known, $\mathrm{Cu}$ is one of the metal element that are biochemically transformed by microorganism to organic metal compounds prior to becoming toxic. Corrosion and scaling are related phenomena and thus, chemical are vital to minimize. In this case, the concentration of $\mathrm{Cu}$ is lower compared to the concentration of Fe. Although $\mathrm{Cu}$ is toxic, since the level of $\mathrm{Cu}$ is $70 \%$ lower compared to the $\mathrm{Fe}$, it will not fully harm the fish. In the meantime, the presence of heavy metals will degrade the water quality and affects the fish or other aquatic animals. It is mainly important for human being. This also implies that the river water is contaminated and polluted with $\mathrm{Cu}$ and $\mathrm{Fe}$, could be attributed to dumping of decaying metal components and also because of submerging the structure of steel cages.

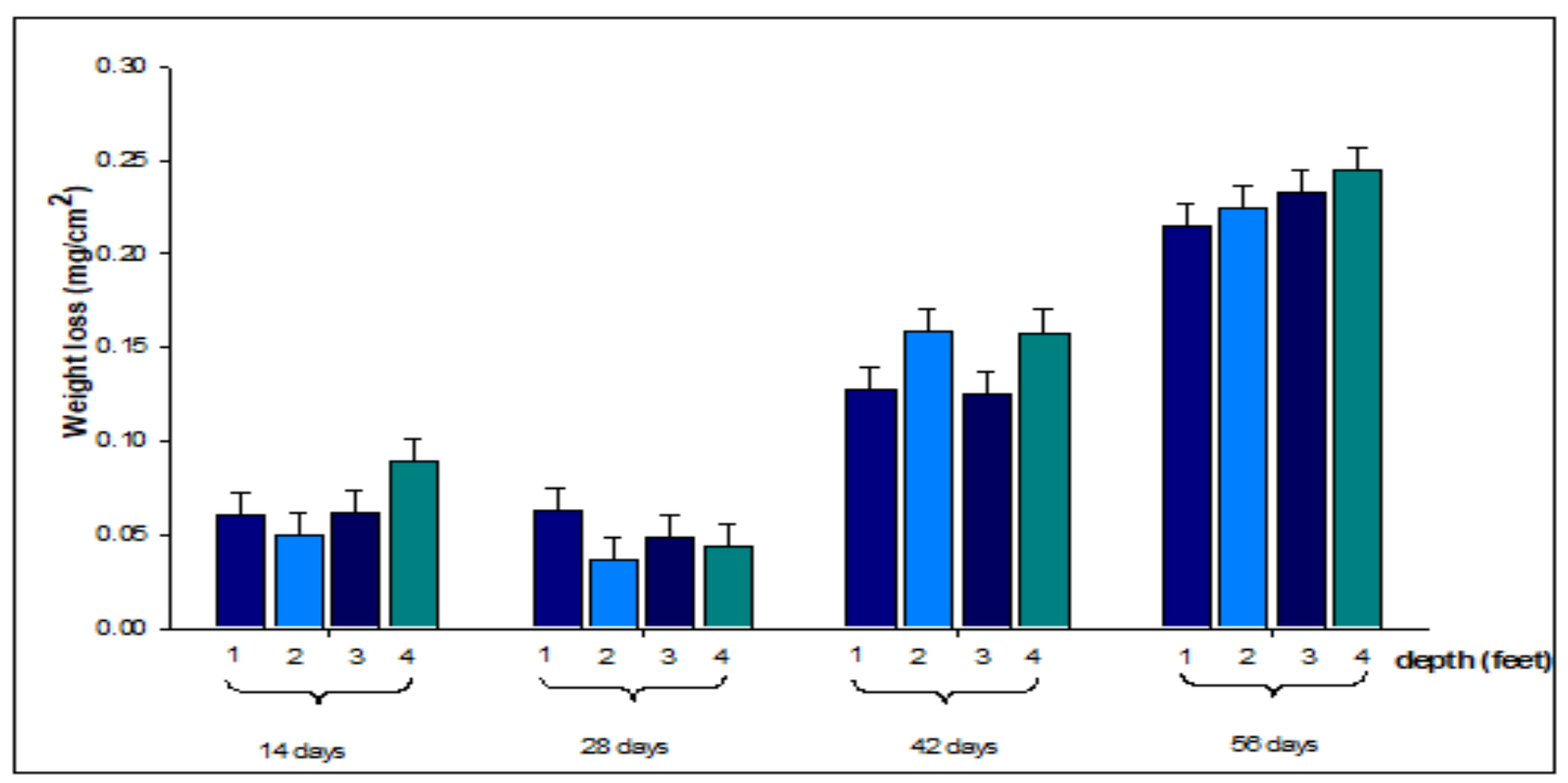

Fig. 5 Weight loss of corroded uncoated y-bar steel submerged in Temerloh, Pahang river water. 


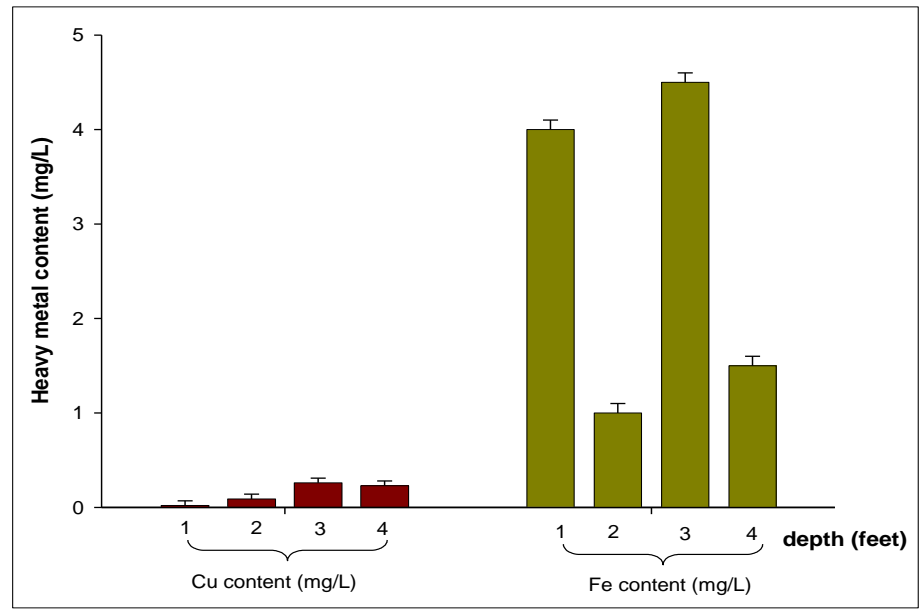

Fig. 6 Heavy metal reading of river water adjacent to the Patin fish cages at 1 to $\mathbf{4} \mathbf{f t}$ depth.

Instead of lack of water flow, the shallow river water level was found due to much water sedimentation caused by deforestation. In this issue, deforestation causes soil erosion due to rain falls and turned the soil to loose. Due to this problem, the river turned brown and become worsen as the soil rushes and falls into the river water. This is in agreement with water turbidity level as shown in Fig. 7. It shows that, the peak of turbidity levels in the river water sampling tended to be higher which is 673 nephelometric turbidity unit (NTU) at $4 \mathrm{ft}$. depth than those in 1, 2 and $3 \mathrm{ft}$. depth. At shallow depth, the water turbidity level is low since it is free from precipitation.

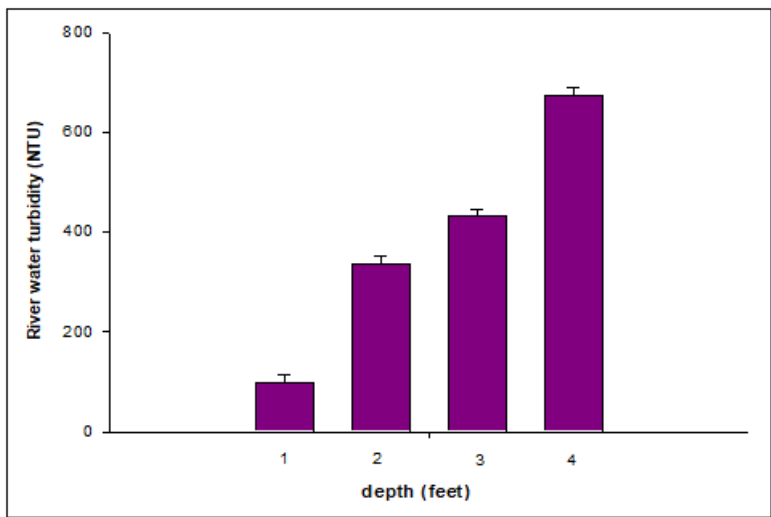

Fig. 7 Water turbidity reading of river water adjacent to the Patin fish cages at 1 to $4 \mathrm{ft}$. depth.

Besides deforestation issue, this problem could be attributed because of the fish movement and the river water velocity. This turbidity brings along all the impurities such as plant, muddy and it was found precipitated below the depth. The source of river water pollution in Patin fish cages usually leads to the higher turbidity level including poor water clarity, algal blooms and lack of submerged plants.

The accumulation of the sedimentation, heavy metal content and also organic waste from fish itself also contributed to the increase of water turbidity level. In addition, turbidity deposits in the river water adjacent to the Patin fish cages would provide a habitat for bacterial growth and hence, could also accelerate the occurrence of total coliform bacteria. Importantly, the Y-bar itself are aggressive to corrosion because of the impurities that precipitate and this can contribute to corrosion where the presence of higher water turbidity level dissolved Fe as it impurities. The river water itself will act as an electrolyte where the Fe ions are dissolved and it is necessary in order to transport ions to and from the metal. Moreover, all these factors involved including the $\mathrm{pH}$, the water turbidity level that shows to have high impurities and organic waste, heavy metal such as $\mathrm{Cu}$ and Fe content and microbial activity, thus, it could promote the degradation of the corroded Y-bar steel.

\section{CONCLUSION}

The findings of this study showed that, the uncoated samples show an increment of weight loss and it was drastically increased after 42 and 56 days of submerging samples in river water. It also shows that after 56 days of the test, uncoated samples show higher weight loss recorded and deeper the depth, the higher the weight loss recorded.

The river water where samples were submerged adjacent to the Patin fish cages shows that the water was contaminated with heavy metal which is $\mathrm{Cu}$ and Fe which can contaminate the living in the river water and hence human. This is due to the low water level issues that lead to the accumulation of the sedimentation, heavy metal content and also organic waste from fish itself and this could contribute to the increase of water turbidity level of the river water sample. Thus, these factors were found could promote and accelerate the degradation of the corroded Y-bar steel ofPatin fish cages structures.

\section{REFERENCES}

1. Ahmad, R. (2015). Floods Hit Cages Breeding Industry Badly, Causing $50 \%$ Drop In Supply. The Star Online.

2. Al-Moubaraki, A. H., Al-Judaibi, A., \&Asiri, M. (2015). Corrosion of C-Steel in the Red Sea: Effect of Immersion Time and Ihibitor Concentration. International Journal of Electrochemical Science, 10 4252-4278.

3. Alawadhi, K., \& Robinson, M. J. (2011). Preferential weld corrosion of X65 pipeline steel in flowing brines containing carbon dioxide. Corrosion Engineering, Science and Technology, 46(4), 318-329.

4. Amadi, S. A., \&Ukpaka, C. P. (2014). Evaluation of Microbiological Corrosion of Carbon Steel in Fresh Water Environment. International Invention Journal of Biochemistry and Bioonformatics, 2(1), 8-13. 
5. Ayer, R., Kleck, C., Miller, M., \& Burger, E. (2017). Bacterial infection of spine instrumentation and microbial induced corrosion (MIC): Chicken or Egg. Biomedical Journal of Scientific \& Technical Research, 1(6), 1-2.

6. Beimeng, Q., Chongwei, C., \&Yixing, Y. (2015). Effects of Iron Bacteria on Cast Iron Pipe Corrosion and Water Quality in Water Distribution Systems. International Journal of Electrochemical Science, 10, 545-558.

7. Fernando, F. (2015). Falling Water Level in Sungai Pahang Makes Fish Breeders See Red. The Rakyat Post.

8. Gasim, M. B., Mokhtar, M., Surif, S., Toriman, M. E., Rahim, A. S., \&Lun, P. I. (2012). Analysis of Thirty Years Recurrent Floods of THe Pahang River, Malaysia. Asia Journal of Earth Sciences, 5, 25-35.

9. Ghorade, I. B., Lamture, S. V, \&Patil, S. S. (2014). Assessment Of Heavy Metal Content In Godavari River Water. International Journal of Research in Applied, Natural and Social Sciences, 2(6), 2347-4580.

10. Hanaa, M. S., Eweida, A., \&Farag, A. (2000). Heavy metals in drinking water and their environmental impact on human health.

11. Ideriah, T. J. K., David-Omiema, S., \&Ogbonna, D. N. (2012). Distribution of Heavy Metals in Water and Sediment along Abonnema Shoreline, Nigeria . Resources and Environment, 2(1), 33-40.

12. Le Chevallier, M. W., \& Welch, N. J. (1996). Full-scale studies of factors related to coliform regrowth in drinking water. Applied and Environmental Microbiology, 62(7), 2201-2211.

13. Lessem, A. S., \& Murphy, J. N. R. (1972). Studies of the dynamics of tracked vehicles. Vicksburg, Mississippi: U. S. Army Engineer Waterways Experiment Station .

14. Malaysia, F. and A. C. P. (n.d.). Information On Fisheries Management In Malaysia.

15. Malaysia, M. of A. and A.-B. I. (Ed.). (2017). Portal RasmiKementerianPertanian\&IndustriAsasTani: Fish Cages Revenue Generator. Putrajaya, Malaysia.

16. Melchers, R. E. (2018). A review of trends for corrosio loss and pit depth in longer-term exposures. Corrosion and Materials Degradation, $1,42-58$.

17. NatSteel. (2015). Reinforcement Bars. Singapore: NatSteel Holdings Pte. Ltd.

18. Reinforcing, O. (2015). Essential Technical Data On Steel Reinforcement (pp. 1-76). pp. 1-76.

19. Subitha, M. V, S., S., Subramanian, K. G., \&Panigrahi, B. S. (2010). Determination of heavy metals in condenser cooling water system of FBTR. Indian Journal of Sciences and Technology, 3(12), 1222-1223.

\section{AUTHORS PROFILE}

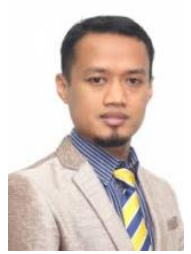

Muhamad Hellmy Hussin, is a lecturer in University of Kuala Lumpur Malaysia France Institute (UNIKL MFI) located at Bandar BaruBangi, Selangor for fourteen years. His expertise is in Innovation and Engineering Design, and also in Corrosion and Failure Analysis. He did his Bac. (Hons.) in Industrial Production Management at the University Nice Sophie Antipolis (UNSA), France, and then pursued his Master Degree in Innovation and Engineering Design at University of Putra Malaysia (UPM) Serdang, Selangor.Over the last eight years he becomes involved in welding and joining research works. And since then he has continued his research and involved in Corrosion and Failure Analysis research areas, Corrosion and failure analysis works. Now, he pursue his PhD in (Mechanical), focusing on High Temperature Corrosion in Hot Gases Environment. He has published articles and journals mainly in Welding and Joining, Corrosion degradation and Failure Analysis research works.

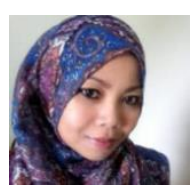

Dr. NurAzida CheLah, is a senior lecturer on Corrosion degradation and Failure Analysis studies at the University of Kuala Lumpur Malaysia France Institute (UNIKL MFI), Bandar BaruBangi, Selangor. She did her Bac (Hons) in Materials Science and then pursued her Master degree in Mechanical Engineering majoring in Fatigue failure Assessment on welded joint at University of Putra Malaysia (UPM) Serdang, Selangor. Her PhD focusing on High Temperature Corrosion Study on Aluminium Welded Joint at The National University of Malaysia (UKM), Bangi, Selangor. And since 2007 she started writing an articles and journals mostly on Fatigue Assessment Analysis, Welding and Joining, Corrosion degradation and Failure Analysis Studies. 